\title{
CONHECIMENTO A FAVOR DO QUÊ?
}

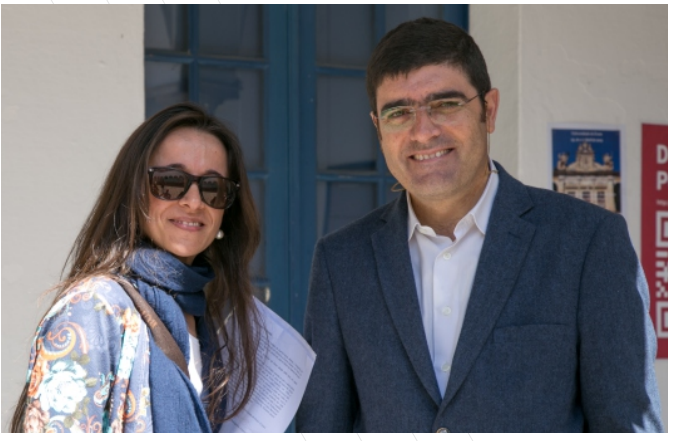

O conhecimento é o centro da atividade de uma Universidade. Produção, divulgação e utilização do conhecimento são três pilares da responsabilidade social de uma academia e estão na base da sua missão. Todo o conhecimento é valioso e útil, independentemente da área em que se inscreve, do processo científico da sua génese, ou do caráter fundamental ou aplicado da sua natureza epistemológica.

Partindo da anterior coordenada conceptual, assumimos, no entanto, que as universidades deverão promover novas fileiras de valorização do conhecimento que produzem, para lá das que, tradicionalmente, já desenvolvem. Mobilizar o conhecimento, de forma solidária e inclusiva, promovendo o acesso dos nossos concidadãos ao exercício dos seus direitos e deveres de cidadania, através de uma abordagem empresarial, na qual o principal valor consiste na criação de oportunidades de desenvolvimento para todos os que participam na fileira, parece-nos uma abordagem possível e necessária nos tempos que vivemos.

Vivemos uma época que nos desafia a inovar, a criar, a tentar construir uma nova realidade social, económica e humana, na qual outros valores se assumam como faróis do novo caminho. $O$ valor das ideias necessita de ser aferido com outras balanças e recorrendo a outras unidades de medida. $\mathrm{O}$ valor medido, exclusivamente, pela riqueza económica que gera continuará a ser importante, mas será, cada vez mais, um valor menor. Dimensões como a sustentabilidade, a inclusão, a participação ou a felicidade estarão associadas às ideias mais valiosas no nosso futuro e distinguirão as academias que as promovam e as sociedades que as acolham. O futuro passará, cremos, por aqui.

O acesso ao conhecimento e a sua consequente utilização são exercícios de cidadania, ainda, hoje, inacessíveis a muitas pessoas, realidade que diminui as suas oportunidades e limita a qualidade das suas vidas. A Educação é e continua(rá) a ser o serviço público mais importante para garantir esse exercício de cidadania. A fileira educativa é a mais valiosa que existe, pois nela se constrói a dimensão estrutural e crítica de todas as outras fileiras de desenvolvimento: o conhecimento.

É nesta moldura axiológica que estamos a desenvolver a nossa ideia de negócio, na área em que investigamos e lecionamos: as Ciências da Educação. Não aspiramos a ganhar muito dinheiro, mas estamos determinados a contribuir para que alguns possam ter uma vida melhor. É isso que é (e será sempre) valioso.

Bravo Nico e Lurdes Pratas Nico, Departamento de Pedagogia e Educação e Centro de Investigação em Educação e Psicologia (CIEP) 